Check for updates

Cite this: RSC Adv., 2018, 8, 5984

Received 18th December 2017

Accepted 24th January 2018

DOI: $10.1039 / c 7 r a 13428 b$

rsc.li/rsc-advances

\section{Interface engineering through electron transport layer modification for high efficiency organic solar cells $\dagger$}

\author{
Kunal Borse, $\star^{\mathrm{ab}}$ Ramakant Sharma, $\dot{t}^{\mathrm{a}}$ Dipti Gupta*a and Aswani Yella (iD *a
}

In the present study, we have compared the device performance of poly[4,8-bis(5-(2-ethylhexyl)thiophen2-yl)benzo[1,2-b;4,5- $\left.b^{\prime}\right]$ dithiophene-2,6-diyl-alt-(4-(2-ethylhexyl)-3-fluorothieno[3,4-b]thio-phene-)-2carb-oxylate-2-6-diyl)] (PTB7-Th):phenyl-C71-butyric acid methyl ester (PCBM) organic solar cells (OSCs) in an inverted geometry with $\mathrm{ZnO}$, a bilayer of $\mathrm{ZnO}$ and $\mathrm{Ba}(\mathrm{OH})_{2}\left[\mathrm{ZnO} / \mathrm{Ba}(\mathrm{OH})_{2}\right]$ and a nanocomposite of $\mathrm{ZnO}$ and $\mathrm{Ba}(\mathrm{OH})_{2} \quad\left[\mathrm{ZnO}: \mathrm{Ba}(\mathrm{OH})_{2}\right]$ as electron transport layers (ETLs). Our study reveals that the performance of the devices with the $\mathrm{ZnO} / \mathrm{Ba}(\mathrm{OH})_{2}$ and $\mathrm{ZnO}: \mathrm{Ba}(\mathrm{OH})_{2}$ nanocomposite as ETL supersedes that of devices with only $\mathrm{ZnO}$ as ETL. The plausible reasons for the improved performance of these devices are identified using morphological studies, contact angle measurements, $\mathrm{X}$-ray photoelectron spectroscopy (XPS), ultraviolet photoelectron spectroscopy (UPS) and photo-electrochemical impedance spectroscopy (EIS) measurements. It is observed that films of $\mathrm{ZnO} / \mathrm{Ba}(\mathrm{OH})_{2}$ and $\mathrm{ZnO}: \mathrm{Ba}(\mathrm{OH})_{2}$ nanocomposites have a low work function and are slightly more smooth and hydrophobic than $\mathrm{ZnO}$ films. This might have suppressed the charge recombination and thereby improved the charge collection as has been confirmed by EIS measurements.

\section{Introduction}

Solution processed bulk-heterojunction organic solar cells (OSCs), which consist of a conjugated polymer as an electron donor and fullerene and/or polymer as an acceptor, are widely regarded as an emerging PV technology and offer many advantages such as mechanical flexibility, low-cost, light weight, low energy consuming roll-to-roll manufacturing process, etc $^{\mathbf{1 - 5}}$ Over the years, to increase the power conversion efficiency (PCE) of OSCs, various strategies have been used. This includes designing and developing new donor and/or acceptor molecules having wide absorption spectra and/or employing various aspects of device and interface engineering such as use of solvent additives for photoactive layer processing, incorporation of metals, dielectric and/or semiconducting nanoparticles (NPs) in the photoactive layer, use of buffer layers like electron and/or hole transport layers, etc. ${ }^{\text {6-12 }}$ It has been demonstrated in the past that the careful selection of electron and/or hole transport layers can improve the PCE by $2-3 \%$ for the same donor:acceptor bulk-heterojunction system. ${ }^{12-17}$

\footnotetext{
${ }^{a}$ Department of Metallurgical Engineering and Materials Science, Indian Institute of Technology Bombay, Powai, Mumbai-400076, India. E-mail: diptig@iitb.ac.in; aswani.yella@iitb.ac.in

${ }^{b}$ Department of Metallurgy, Government Polytechnic, Kolhapur-416004, India

$\dagger$ Electronic supplementary information (ESI) available. See DOI: 10.1039/c7ra13428b

\$ Kunal Borse and Ramakant Sharma contributed equally to this work.
}

Till date several types of material and/or their nanocomposites have been used as an electron transport layers (ETLs). ${ }^{\mathbf{2 1 8 - 2 0}}$ Among them the most preferred ones are solution processed metal oxides $\left(\mathrm{MeO}_{x}\right)$ like $\mathrm{ZnO}, \mathrm{TiO}_{2}, \mathrm{ZrO}_{2}$, etc. ${ }^{21-23}$ This is quite obvious as most of these $\mathrm{MeO}_{x}$ offer good airstability, high transparency to visible light, high electron affinity, and tuneable electrical and optical properties. ${ }^{24,25}$ However, being a solution processed and low temperature processed, these $\mathrm{MeO}_{x}$ often digress from the properties of single crystals and as a result, many-a-times, it is observed that defect related energy levels or Schottky barriers form interfacial barriers. ${ }^{26}$ Besides $\mathrm{MeO}_{x}$, organic dipole layers such as conjugated polyelectrolytes (CPE), ${ }^{2,27-29}$ organic salts, zwitterions and cost effective poly(ethyleneimine) (PEI) ${ }^{19}$ or poly(ethyleneimine)-ethoxylated (PEIE) ${ }^{20}$ does modify the work function and has been used an ETL. Most of them can simply be spin-coated in ambient atmosphere just like $\mathrm{MeO}_{x}$ and helps in simplifying the fabrication method. However, the insulating nature of these types of materials often leads to high series resistance in a thick film and therefore the performance of devices was found to be highly sensitive to the thickness of these layers. ${ }^{30-32}$

To overcome these issues, in recent times, two alternate approaches which include use of bilayer structure such as $\mathrm{MeO}_{x} / \mathrm{PEI}(\mathrm{PEIE} / \mathrm{PFN})$ and $\mathrm{MeO}_{x}$ :PEI (PEIE/PFN) nanocomposite as an ETL have been studied. ${ }^{19,20,33,34}$ Although the bilayer structure improves the PCE of the devices, the high thickness sensitivity of performance caused by PEI (PEIE) still can't be 
solved. ${ }^{30-32}$ On the other hand, $\mathrm{MeO}_{x}$ :PEI (PEIE/PFN) nanocomposite offers combined advantages such as the high charge carrier mobility of $\mathrm{MeO}_{x}$ and good film formation ability of polymer..$^{33-35}$ As a result, devices with nanocomposite as an ETL often demonstrate high PCE and good stability. Recently, lessstudied type of inorganic salt, barium hydroxide $\left[\mathrm{Ba}(\mathrm{OH})_{2}\right]$ has been explored as an ETL so as to improve device performance in polymer light-emitting diodes (PLEDs), ${ }^{36}$ organic field effect transistors (OFETs), ${ }^{37}$ OSCs owing to its outstanding charge injection ability. A remarkable enhancement in PCE of OSCs has been demonstrated by employing $\mathrm{Ba}(\mathrm{OH})_{2}$ as an ETL or upon inserting a $\mathrm{Ba}(\mathrm{OH})_{2}$ layer between photoactive layer and ETLs. ${ }^{26,38}$ Both this approaches contribute to reduction of energetic barrier at the interface and improves charge collection.

Here in, we have adopted a novel approach in which we have blended a sol-gel $\mathrm{ZnO}$ solution with a $\mathrm{Ba}(\mathrm{OH})_{2}$ solution prior to their final consolidation into the nanocomposite layer as the ETL. From the similar type of previous studies, we presume that the presence of $\mathrm{Ba}(\mathrm{OH})_{2}$ in $\mathrm{ZnO}$ might induce stronger electrostatic or dipole-dipole interactions with a $\mathrm{ZnO}$ surface and therefore use of $\mathrm{ZnO}: \mathrm{Ba}(\mathrm{OH})_{2}$ nanocomposites as ETLs would improve the device performance of OSCs. Devices were fabricated in an inverted geometry having a structure ITO/ZnO or bilayer of $\mathrm{ZnO}$ and $\mathrm{Ba}(\mathrm{OH})_{2}\left[\mathrm{ZnO} / \mathrm{Ba}(\mathrm{OH})_{2}\right]$ or nanocomposite of $\mathrm{ZnO}$ and $\mathrm{Ba}(\mathrm{OH})_{2}\left[\mathrm{ZnO}: \mathrm{Ba}(\mathrm{OH})_{2}\right]$ nanocomposites $(40 \mathrm{~nm}) /$ PTB7-Th:PCBM(100 nm)/ $\mathrm{MoO}_{3}(10 \mathrm{~nm}) / \mathrm{Ag}$ (100 nm). Our study reveals that the performance of the devices with $\mathrm{ZnO} /$ $\mathrm{Ba}(\mathrm{OH})_{2}$ and $\mathrm{ZnO}: \mathrm{Ba}(\mathrm{OH})_{2}$ nanocomposite as ETL supersedes that of devices with only ZnO as ETL. The plausible reasons for the improved performance of these devices are identified using contact angle measurements, atomic force microscopy (AFM), X-ray photoelectron spectroscopy (XPS), ultraviolet photoelectron spectroscopy (UPS) and photo-EIS measurements.

\section{Experimental}

\subsection{Preparation of sol gel $\mathrm{ZnO}$}

Sol gel ZnO was prepared by the method reported in our previous work. ${ }^{39}$ At first, equimolar (0.25 M) solution of zinc acetate dihydrate (Aldrich, 99.9\%) and ethanolamine was prepared in $10 \mathrm{ml}$ of 2-methoxy ethanol. Thereafter, solution was allowed to stir rigorously for $12 \mathrm{~h}$ at $70{ }^{\circ} \mathrm{C}$ to get a homogeneous, clear and transparent solution. Thereafter solution was aged for $24 \mathrm{~h}$ before using it for spin-coating as an electron transport layer.

\subsection{Preparation of barium hydroxide solution}

The barium hydroxide solution was prepared by dissolving barium hydroxide in 2-methoxyethanol $\left(2 \mathrm{mg} \mathrm{ml}^{-1}\right){ }^{26,38}$ The $\mathrm{Ba}(\mathrm{OH})_{2}$ solution was filtered by a nylon filter with a diameter of $0.45 \mu \mathrm{m}$ prior to the spin-cast.

\subsection{Preparation of zinc oxide/barium hydroxide nanocomposites}

For preparation of $\mathrm{ZnO}: \mathrm{Ba}(\mathrm{OH})_{2}$ nanocomposite, $\mathrm{ZnO}$ stock solution was mixed with a set amount of $\mathrm{Ba}(\mathrm{OH})_{2}$ solution $(3,6$,
9 and $12 \mathrm{w} / \mathrm{w} \%$ ) and stirred vigorously for $12 \mathrm{~h}$. As obtained solutions were filtered by a nylon filter with a diameter of 0.45 $\mu \mathrm{m}$ prior to the spin-cast.

\subsection{Device fabrication}

Devices were fabricated following the device architecture mentioned in the Fig. 1(a) and corresponding energy levels of the materials used in the fabrication are shown in the Fig. 1(b). ${ }^{38,39}$ At first, photoactive blend comprised of PTB7-Th (10 mg) and PCBM (15 mg) was prepared in $1 \mathrm{ml}$ of DCB with $3 \% \mathrm{v} / \mathrm{v}$ of 1,8 -diiodooctane (DIO) solvent as an additive. The solution was allowed to stir at $70{ }^{\circ} \mathrm{C}$ in the dark for at least $12 \mathrm{~h}$. For the device fabrication, ITO coated glass substrates (Luminescence Technology corp. Taiwan, with a sheet resistance of 15 $\Omega \mathrm{sq}^{-1}$ and transmittance $>85 \%$ ) were cleaned by process reported in our previous work. ${ }^{7,40}$ For the devices with $\mathrm{ZnO}$ and $\mathrm{ZnO}: \mathrm{Ba}(\mathrm{OH})_{2}$ nanocomposite as an ETL, $\mathrm{ZnO}$ and $\mathrm{ZnO}: \mathrm{Ba}(\mathrm{OH})_{2}$ nanocomposite solutions which was previously synthesized, was spin-coated on pre-cleaned ITO substrates at $2000 \mathrm{rpm}$ for $30 \mathrm{~s}$ to obtain a film of $\sim 40 \mathrm{~nm}$. The substrates were then annealed at $200{ }^{\circ} \mathrm{C}$ for $15 \mathrm{~min}$ to remove excess solvents. Thereafter, substrates were transferred inside nitrogen filled glove box and a photoactive blend was spin-coated at $1100 \mathrm{rpm}$ for $120 \mathrm{~s}$. The films were allowed to get dried for $2 \mathrm{~h}$ and then subsequently, the devices were evaporated using the shadow mask by thermal evaporation of $10 \mathrm{~nm} \mathrm{MoO}_{3}$ layer as a hole transport layer and $100 \mathrm{~nm} \mathrm{Ag}$ electrode as anode. For the devices with $\mathrm{ZnO} / \mathrm{Ba}(\mathrm{OH})_{2}$, an additional layer of $\mathrm{Ba}(\mathrm{OH})_{2}$ was spin-coated on the top of $\mathrm{ZnO}$ layer and allowed to dry before spin-coating the photoactive layer. Thereafter the film is annealed at $200{ }^{\circ} \mathrm{C}$ for $5 \mathrm{~min}$ to remove excess solvent if any.

(a)

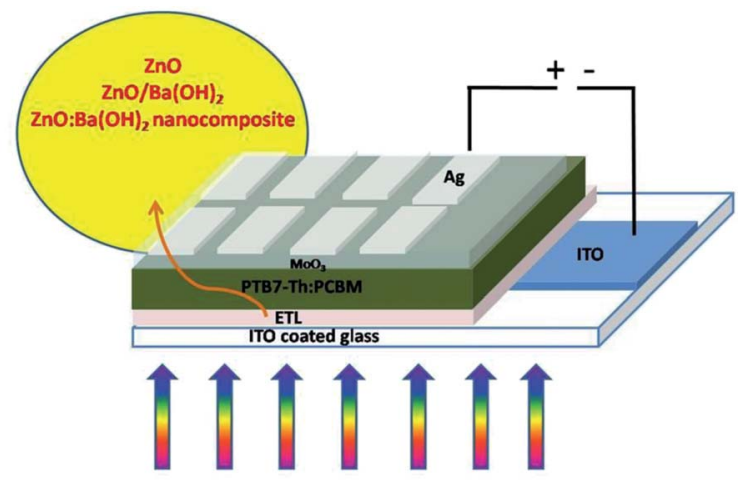

(b)

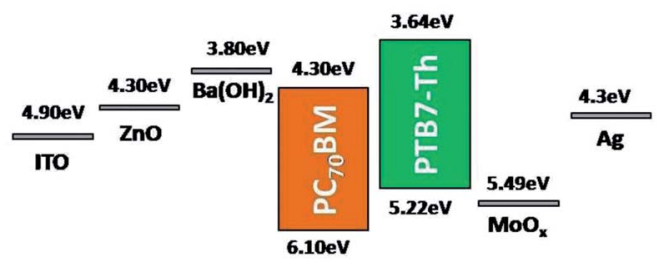

Fig. 1 (a) Schematic of PTB7-Th:PCBM OSCs in an inverted geometry with $\mathrm{ZnO}, \mathrm{ZnO} / \mathrm{Ba}(\mathrm{OH})_{2}$ and $\mathrm{ZnO}: \mathrm{Ba}(\mathrm{OH})_{2}$ nanocomposite as ETLs (b) energy levels of materials used in the solar cell device. 


\subsection{Device characterization and testing}

The current density-voltage $(J-V)$ characteristics curves of fabricated devices were measured using a Keithley 2600 source meter and a Newport solar simulator (model number 91160) shines light with AM 1.5 G spectral distribution, which was calibrated using a certified reference solar cell to an intensity of $1000 \mathrm{~W} \mathrm{~m}^{-2}$. External quantum efficiency (EQE) spectra were obtained from Bentham's PVE300. The test cells were masked with a single aperture and care has been taken to exclude all light from entering the cell elsewhere, including shading of the edges of the substrates. The active device area is defined as 4.5 $\mathrm{mm}^{2}$ by using a shadow mask. Conductivity measurements of various ETLs were performed by Broadband Dielectric Spectroscopy at room temperature using Alpha-A high performance frequency analyser.

\section{Results and discussion}

Fig. 2(a) and (b) presents the $J-V$ characteristics curves and external quantum efficiency (EQE) spectra of devices with different ETLs. Photovoltaic parameters such as open circuit voltage $\left(V_{\mathrm{oc}}\right)$, short-circuit current density $\left(J_{\mathrm{sc}}\right)$, fill factor $(\mathrm{FF})$, and PCE for the devices with $\mathrm{ZnO}, \mathrm{ZnO} / \mathrm{Ba}(\mathrm{OH})_{2}$ and $\mathrm{ZnO}: \mathrm{Ba}(\mathrm{OH})_{2}(9 \mathrm{wt} \%)$ nanocomposite as an ETL are shown in Table 1 and for all the fabricated devices are summarized in Table S1. $\dagger$ As can be seen, for the control device with only $\mathrm{ZnO}$ as an ETL, $V_{\text {oc }}, J_{\text {sc }}$, FF and PCE are $803 \mathrm{mV}, 14.28 \mathrm{~mA} \mathrm{~cm}^{-2}$, $62.30 \%$ and $7.12 \%$ respectively. However, for the devices with $\mathrm{ZnO} / \mathrm{Ba}(\mathrm{OH})_{2}$ and $\mathrm{ZnO}: \mathrm{Ba}(\mathrm{OH})_{2}$ nanocomposite as an ETL, improvement in performance parameters are noticed. As a result, devices with $\mathrm{ZnO} / \mathrm{Ba}(\mathrm{OH})_{2}$ and $\mathrm{ZnO}: \mathrm{Ba}(\mathrm{OH})_{2}$ nanocomposite as an ETL demonstrates PCE of 8.54 and $8.66 \%$ respectively. This is roughly $20 \%$ increase when compared to
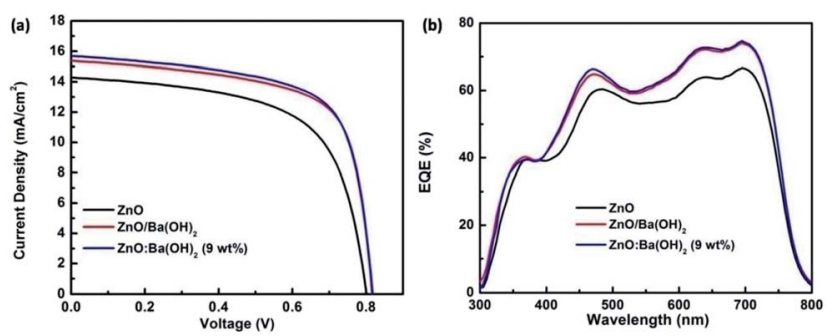

Fig. 2 (a) $J-V$ characteristics under illumination (AM $1.5 \mathrm{G}$, one sun) and (b) EQE spectra of devices with $\mathrm{ZnO}, \mathrm{ZnO} / \mathrm{Ba}(\mathrm{OH})_{2}$ and $\mathrm{ZnO}: \mathrm{Ba}(\mathrm{OH})_{2}$ nanocomposite as an ETLs. the devices with only ZnO as an ETL. Although there is a slight change in the $V_{\text {oc }}$, it can be observed that the increase in the PCE mainly arises mainly due to increase in the $J_{\mathrm{sc}}$ and $\mathrm{FF}$ for devices with $\mathrm{ZnO} / \mathrm{Ba}(\mathrm{OH})_{2}$ and $\mathrm{ZnO}: \mathrm{Ba}(\mathrm{OH})_{2}$ nanocomposite as an ETL. Increase in the $J_{\mathrm{sc}}$ is also confirmed from the EQE measurements. $J_{\text {sc }}$ calculated from the EQE spectra of the three devices are shown in the Table 1 and for all the fabricated devices in Table S1. $\dagger$ Maximum EQE of $\sim 70 \%$ is achieved in the case of devices with $\mathrm{ZnO} / \mathrm{Ba}(\mathrm{OH})_{2}$ and $\mathrm{ZnO}: \mathrm{Ba}(\mathrm{OH})_{2}$ (9 wt\%) nanocomposite as an ETL as against $\sim 62 \%$ for the devices with only $\mathrm{ZnO}$ as an ETL. To investigate the plausible reasons for the improved performance and performance parameters like $V_{\mathrm{oc}}$, $J_{\text {sc }}$, FF of devices with $\mathrm{ZnO} / \mathrm{Ba}(\mathrm{OH})_{2}$ and $\mathrm{ZnO}: \mathrm{Ba}(\mathrm{OH})_{2}(9 \mathrm{wt} \%)$ nanocomposite as an ETL, morphological studies, contact angle measurements, XPS, UPS and photo-EIS measurements are carried out and has been discussed below.

From the previous studies, it is well understood that better hydrophobic properties of ETLs are essential for the intimate contact with the deposited photoactive layer which is spincoated from dispersion in an organic solvent. ${ }^{\mathbf{4 1 4 2}}$ Thus, contact angle measurements were carried out with water drop as the probe for the surface of $\mathrm{ZnO}, \mathrm{ZnO} / \mathrm{Ba}(\mathrm{OH})_{2}$ and $\mathrm{ZnO}: \mathrm{Ba}(\mathrm{OH})_{2}(9 \mathrm{wt} \%)$ nanocomposite and subsequent values are shown in Table 2 and for all the all the films studies, contact angle values are summarized in Table S2. $\dagger$ From both these tables, two observations were made: (1) it can be seen that in both cases i.e. $\mathrm{ZnO} / \mathrm{Ba}(\mathrm{OH})_{2}$ and for all the composition of $\mathrm{ZnO}: \mathrm{Ba}(\mathrm{OH})_{2}$ nanocomposite, contact angle is more than $\mathrm{ZnO}$ (2) it is observed that contact angle increases with the increase in the wt $\%$ of $\mathrm{Ba}(\mathrm{OH})_{2}$ in $\mathrm{ZnO}: \mathrm{Ba}(\mathrm{OH})_{2}$ nanocomposite and saturates at around $\sim 52^{\circ}$ for all the compositions after $6 \mathrm{wt} \%$. From both these observations, it is confirmed that films of $\mathrm{ZnO} /$ $\mathrm{Ba}(\mathrm{OH})_{2}$ and $\mathrm{ZnO}: \mathrm{Ba}(\mathrm{OH})_{2}$ nanocomposite are somewhat more hydrophobic than that of $\mathrm{ZnO}$. But this small increment in contact angle for the films of $\mathrm{ZnO} / \mathrm{Ba}(\mathrm{OH})_{2}$ and $\mathrm{ZnO}: \mathrm{Ba}(\mathrm{OH})_{2}$ nanocomposite could not be the only reason for the improved PCE and therefore role of morphology and surface topography

Table 2 Contact angle of the surface of films of $\mathrm{ZnO}, \mathrm{ZnO} / \mathrm{Ba}(\mathrm{OH})_{2}$ and $\mathrm{ZnO}: \mathrm{Ba}(\mathrm{OH})_{2}$ nanocomposite thin films deposited on ITO coated glass substrates

\begin{tabular}{ll}
\hline Electron transport layer (ETL) $\quad$ Contact angle (in deg) \\
\hline
\end{tabular}

$\begin{array}{ll}\mathrm{ZnO} & 46.88 \pm 0.65\end{array}$

$\mathrm{ZnO} / \mathrm{Ba}(\mathrm{OH})_{2} \quad 49.59 \pm 0.54$

$\mathrm{ZnO}: \mathrm{Ba}(\mathrm{OH})_{2}(9 \mathrm{wt} \%) \quad 52.65 \pm 0.81$

Table 1 Performance parameters for devices with $\mathrm{ZnO}, \mathrm{ZnO} / \mathrm{Ba}(\mathrm{OH})_{2}$ and $\mathrm{ZnO}: \mathrm{Ba}(\mathrm{OH})_{2}$ nanocomposite as an ETLs

\begin{tabular}{|c|c|c|c|c|}
\hline Electron transport layer (ETL) & $V_{\text {oc }}(\mathrm{mV})$ & $J_{\mathrm{sc}}{ }^{a}\left(\mathrm{~mA} \mathrm{~cm}^{-2}\right)$ & $\mathrm{FF}(\%)$ & $\operatorname{PCE}^{b}(\%)$ \\
\hline $\mathrm{ZnO}$ & 803 & $14.28(14.05)$ & 62.30 & $7.12(7.07)$ \\
\hline $\mathrm{ZnO} / \mathrm{Ba}(\mathrm{OH})_{2}$ & 814 & $15.34(15.56)$ & 68.20 & $8.54(8.46)$ \\
\hline
\end{tabular}

${ }^{a} J_{\mathrm{sc}}$ as calculated from EQE is shown in parentheses. ${ }^{b}$ The average PCE is shown in parentheses. Average PCE was calculated using the results of 5 devices. 


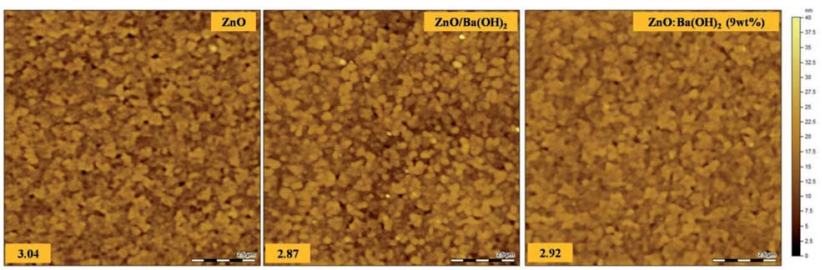

Fig. 3 Atomic Force Microscopy (AFM) images of $\mathrm{ZnO}, \mathrm{ZnO} / \mathrm{Ba}(\mathrm{OH})_{2}$ and $\mathrm{ZnO}: \mathrm{Ba}(\mathrm{OH})_{2}(9 \mathrm{wt} \%)$ nanocomposite thin films deposited on ITO coated glass substrates.

of ETL is investigated thereafter. It has been well known that the interfacial morphology and surface topography of ETL plays a crucial role and can significantly influence the device performance. ${ }^{43,44}$ Surface morphology and RMS surface roughness of $\mathrm{ZnO}, \mathrm{ZnO} / \mathrm{Ba}(\mathrm{OH})_{2}$ and $\mathrm{ZnO}: \mathrm{Ba}(\mathrm{OH})_{2}(9 \mathrm{wt} \%)$ nanocomposite thin films deposited on ITO coated glass substrates are shown in the Fig. 3. It was observed that although the morphology of all the three films are quite similar but RMS surface roughness of the $\mathrm{ZnO} / \mathrm{Ba}(\mathrm{OH})_{2}$ and $\mathrm{ZnO}: \mathrm{Ba}(\mathrm{OH})_{2}(9 \mathrm{wt} \%)$ nanocomposite thin films are slightly less as compared to the ZnO. Thus, we believe that smooth surface of these film facilitates with slightly higher contact angle might be facilitating uniform, conformal and intimate contact with the PTB7-Th:PCBM photoactive layer therefore devices with $\mathrm{ZnO} / \mathrm{Ba}(\mathrm{OH})_{2}$ and $\mathrm{ZnO}: \mathrm{Ba}(\mathrm{OH})_{2}(9 \mathrm{wt} \%)$ nanocomposite thin films as an ETL performs better than devices with only ZnO as an ETL.

To confirm and demonstrate the presence of $\mathrm{Ba}$ in $\mathrm{ZnO} /$ $\mathrm{Ba}(\mathrm{OH})_{2}$ and $\mathrm{ZnO}: \mathrm{Ba}(\mathrm{OH})_{2}(9 \mathrm{wt} \%)$ nanocomposite, XPS survey spectra of $\mathrm{ZnO}, \mathrm{ZnO} / \mathrm{Ba}(\mathrm{OH})_{2}$ and $\mathrm{ZnO}: \mathrm{Ba}(\mathrm{OH})_{2}(9 \mathrm{wt} \%)$ nanocomposite acquired in the range of $0-1170 \mathrm{eV}$ have been taken and are illustrated in Fig. 4(a). During photoemission studies, specimen charging was observed which was later calibrated by assigning the $\mathrm{C} 1 \mathrm{~s}$ signal at $284.6 \mathrm{eV}$. To get the clean surface $\mathrm{Ar}$ ion sputtering performed on all three samples for $20 \mathrm{~min}$ with average base pressure maintained $6 \times 10^{-8}$ torr. Survey spectra of Fig. 4(a) show sharp peaks of C 1s (284.6 eV), O 1s (531 eV) along with the expected peaks of $\mathrm{Zn}$ and Ba. Auger peak for $\mathrm{Zn}$ (LMM) was also observed. For $\mathrm{ZnO}, \mathrm{ZnO} / \mathrm{Ba}(\mathrm{OH})_{2}$ and $\mathrm{ZnO}: \mathrm{Ba}(\mathrm{OH})_{2}(9 \mathrm{wt} \%)$ nanocomposite, two prominent peaks at $\sim 1021.75 \mathrm{eV}$ and $\sim 1044.25 \mathrm{eV}$ can be attributed to $\mathrm{Zn}\left(2 \mathrm{p}_{3 / 2}\right) \&$ $\mathrm{Zn}\left(2 \mathrm{p}_{1 / 2}\right)$, which confirms the presence of $\mathrm{ZnO}$ phase formation. ${ }^{23} \mathrm{Also}$, for $\mathrm{ZnO} / \mathrm{Ba}(\mathrm{OH})_{2}$, two prominent peaks at $\sim 781 \mathrm{eV}$
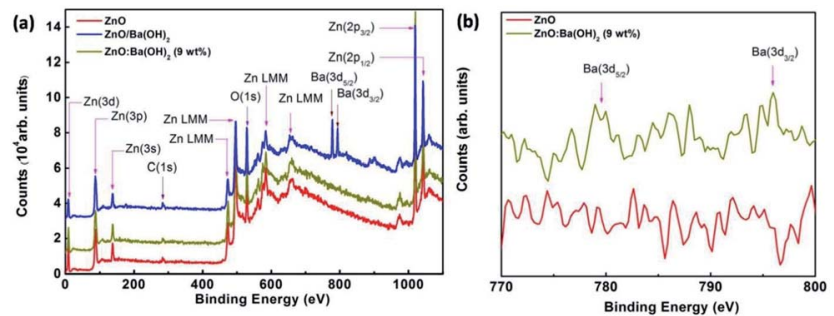

Fig. 4 (a) XPS Survey scan spectra of $\mathrm{ZnO}, \mathrm{ZnO} / \mathrm{Ba}(\mathrm{OH})_{2}$ and $\mathrm{ZnO}: \mathrm{Ba}(\mathrm{OH})_{2}$ (9 wt\%) nanocomposite thin films deposited on ITO coated glass substrates. (b) XPS core level spectra of $\mathrm{ZnO}$ and $\mathrm{ZnO}: \mathrm{Ba}(\mathrm{OH})_{2}(9 \mathrm{wt} \%)$ nanocomposite. and $\sim 796 \mathrm{eV}$ can be attributed to $\mathrm{Ba}\left(3 \mathrm{~d}_{5 / 2}\right) \& \mathrm{Zn}\left(3 \mathrm{~d}_{3 / 2}\right) .{ }^{45}$ However, the intensity of these peaks decreases significantly in the case of $\mathrm{ZnO}: \mathrm{Ba}(\mathrm{OH})_{2}$ (9 $\mathrm{wt} \%$ ) nanocomposite and these peaks are absent in the case of $\mathrm{ZnO}$ as can be seen in the Fig. 4(b). Thus, it is confirmed that Ba exist in both $\mathrm{ZnO} /$ $\mathrm{Ba}(\mathrm{OH})_{2}$ and $\mathrm{ZnO}: \mathrm{Ba}(\mathrm{OH})_{2}(9 \mathrm{wt} \%)$ nanocomposite.

As discussed in the previous section of this paper, the increase in the PCE for devices with $\mathrm{ZnO} / \mathrm{Ba}(\mathrm{OH})_{2}$ and $\mathrm{ZnO}: \mathrm{Ba}(\mathrm{OH})_{2}$ nanocomposite as an ETL is mainly due to increase in the $J_{\mathrm{sc}}$ and FF. It is well known from the previous studies that $J_{\mathrm{sc}}$ depends on the photon absorption which is material property of donor polymer and both $J_{\mathrm{sc}}$ and FF depends on intrinsic mobility of donor and acceptor, morphology of photoactive and buffer layers and energy level of buffer layers used. $^{46}$ In the present study, photon absorption, intrinsic mobility of donor and acceptor, morphology of photoactive layer must be same for the three devices as same photoactive layer comprised of PTB7-Th:PCBM has been employed. Further, as discussed in the previous section, there is a slight difference in the morphology, surface roughness and hydrophobic properties of films of $\mathrm{ZnO}, \mathrm{ZnO} / \mathrm{Ba}(\mathrm{OH})_{2}$ and $\mathrm{ZnO}: \mathrm{Ba}(\mathrm{OH})_{2}$ nanocomposite. Thus, it is presumed that there must be the change in the energy levels of these films which is responsible for the increase in the PCE of devices with $\mathrm{ZnO} / \mathrm{Ba}(\mathrm{OH})_{2}$ and $\mathrm{ZnO}: \mathrm{Ba}(\mathrm{OH})_{2}$ nanocomposite as an ETL. To verify this presumption, UPS measurements are carried out to study the surface electronic energy levels $\mathrm{ZnO}, \mathrm{ZnO} / \mathrm{Ba}(\mathrm{OH})_{2}$ and $\mathrm{ZnO}: \mathrm{Ba}(\mathrm{OH})_{2}(9 \mathrm{wt} \%)$ nanocomposite thin films and results are shown in Fig. 5(a) and (b). The HOMO level of $\mathrm{ZnO}, \mathrm{ZnO} /$ $\mathrm{Ba}(\mathrm{OH})_{2}$ and $\mathrm{ZnO}: \mathrm{Ba}(\mathrm{OH})_{2}$ (9 wt\%) nanocomposite thin films are found to be $7.58,7.52$ and $7.28 \mathrm{eV}$ respectively. This trend is similar to the trend reported for previously reported different ZnO based nanocomposite. ${ }^{34}$ Thus, it is clear that HOMO level of the $\mathrm{ZnO} / \mathrm{Ba}(\mathrm{OH})_{2}$ and $\mathrm{ZnO}: \mathrm{Ba}(\mathrm{OH})_{2}$ nanocomposite thin films are lower than that of $\mathrm{ZnO}$ (Table 3). The HOMO level was determined by the eqn (1) mentioned in the previous studies: ${ }^{20,47}$

$$
\text { HOMO level }=h \nu-\left(E_{1}-E_{2}\right)
$$

Here, $h v$ is incident photon energy $(21.2 \mathrm{eV})$ of He I, and values of $E_{1}$ and $E_{2}$ are for $\mathrm{ZnO}, \mathrm{ZnO} / \mathrm{Ba}(\mathrm{OH})_{2}$ and $\mathrm{ZnO}: \mathrm{Ba}(\mathrm{OH})_{2}$ $(9 \mathrm{wt} \%)$ nanocomposite thin films are shown in Table $3 .^{33,47}$ The
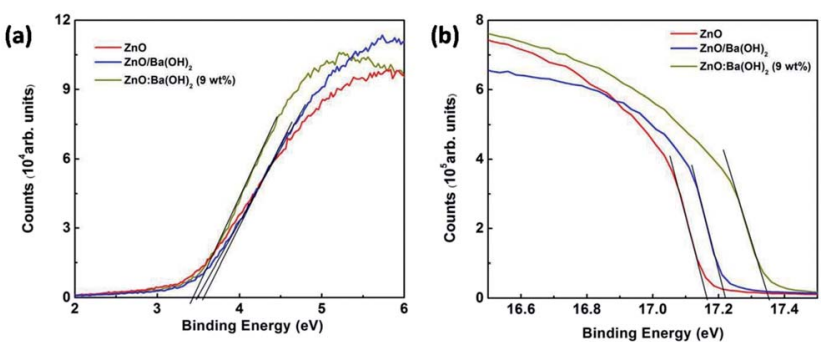

Fig. 5 UPS spectra of $\mathrm{ZnO}, \mathrm{ZnO} / \mathrm{Ba}(\mathrm{OH})_{2}$ and $\mathrm{ZnO}: \mathrm{Ba}(\mathrm{OH})_{2}$ (9 wt\%) nanocomposite thin films deposited on ITO coated glass substrates (a) valence band region (b) cut-off region. 
Table 3 Various energy levels of $\mathrm{ZnO}, \mathrm{ZnO} / \mathrm{Ba}(\mathrm{OH})_{2}$ and $\mathrm{ZnO}: \mathrm{Ba}(\mathrm{OH})_{2}(9$ wt\%) nanocomposite thin films deposited on ITO coated glass substrates $^{a}$

\begin{tabular}{llllll}
\hline Electron transport layer (ETL) & $E_{1}$ & $E_{2}$ & $\Delta E$ & HOMO & $E_{\mathrm{g}}$ \\
\hline $\mathrm{ZnO}$ & 17.16 & 3.53 & 13.63 & 7.58 & 3.22 \\
$\mathrm{ZnO} / \mathrm{Ba}(\mathrm{OH})_{2}(9 \mathrm{wt} \%)$ & 17.22 & 3.53 & 13.66 & 7.52 & 4.36 \\
$\mathrm{ZnO}: \mathrm{Ba}(\mathrm{OH})_{2}(17.36$ & 3.43 & 13.93 & 7.28 & 3.29 & 3.34
\end{tabular}

${ }^{a} E_{1}$ is upper emission onset energies and $E_{2}$ is the lower emission onset energies.

$E_{1}$ was determined by linear extrapolation to zero at the yield of secondary electrons, and the $E_{2}$ is the onset relative to the Fermi level $\left(E_{\mathrm{f}}\right)$ of $\mathrm{Au}(0 \mathrm{eV})$, where the $E_{\mathrm{f}}$ is determined from the $\mathrm{Au}$ substrate. ${ }^{47}$ The LUMO level of $\mathrm{ZnO}, \mathrm{ZnO} / \mathrm{Ba}(\mathrm{OH})_{2}$ and $\mathrm{ZnO}: \mathrm{Ba}(\mathrm{OH})_{2}(9 \mathrm{wt} \%)$ nanocomposite thin films is determined by using eqn (2) mentioned in the previous studies: ${ }^{47}$

$$
\text { LUMO = HOMO - optical band gap, }
$$

The LUMO levels of $\mathrm{ZnO}, \mathrm{ZnO} / \mathrm{Ba}(\mathrm{OH})_{2}$ and $\mathrm{ZnO}: \mathrm{Ba}(\mathrm{OH})_{2}$ (9 $\mathrm{wt} \%$ ) nanocomposite thin films are found to be 4.36, 4.26 and $3.94 \mathrm{eV}$ respectively. Thus, it is evident that the LUMO of the $\mathrm{ZnO} / \mathrm{Ba}(\mathrm{OH})_{2}$ and $\mathrm{ZnO}: \mathrm{Ba}(\mathrm{OH})_{2}(9 \mathrm{wt} \%)$ nanocomposite thin films is smaller than that of $\mathrm{ZnO}$. This trend is expected and can be explained based on the mechanism reported in the previous studies in which they have discussed the formation of a low work function $\mathrm{Zn}-\mathrm{O}-\mathrm{Ba}$ complex..6,48 $\mathrm{Their}$ study suggests that a thin layer of $\mathrm{O}-\mathrm{Ba}$ is formed on the $\mathrm{ZnO}$ surface with $\mathrm{Ba}$ ions pointing upwards. Further, the formation of O-Ba replaces the hydroxyl group on the $\mathrm{ZnO}$ surface by surface chemical reaction: ${ }^{-} \mathrm{OH}+\mathrm{Ba}^{+} \rightarrow \mathrm{O}-\mathrm{Ba}+\mathrm{H}^{+}$, a phenomenon similar to chemisorption of Cl-terminated molecules onto ITO. The interface dipoles with a negative charge toward $\mathrm{ZnO}$ and the corresponding positive charge toward the upward direction result in the lowering of the vacuum level of $\mathrm{ZnO}$ and this might be facilitating the charge transport from PCBM to ETLs. ${ }^{21,48}$ Further, variation in conductivities of the ETLs are given in Fig. S1b of ESI $\dagger$ and device performance of various devices was compared with the intensity dependent photo-EIS measurements and has been discussed in the subsequent section.

Fig. S3 $\uparrow$ illustrates Nyquist plot (both raw and fitted) of PTB7Th:PCBM OSCs with $\mathrm{ZnO}, \mathrm{ZnO} / \mathrm{Ba}(\mathrm{OH})_{2}$ and $\mathrm{ZnO}: \mathrm{Ba}(\mathrm{OH})_{2}$ nanocomposite as ETLs under different illumination intensity. It can be clearly seen that for all the three ETLs, photo-EIS spectra as shown in the Fig. S3(a-c) $\dagger$ consist of only one semicircle. This is in agreement with the previous reports of PTB7Th:PCBM OSC and can be explained on the basis of molecular packaging of donor polymer. ${ }^{49,50}$ In the case of PTB7-Th, like other low bandgap donor polymers, it is a face-on orientation making the inter-electrode transport proceeds through the $\pi-\pi$ stacking. As a result, the second semicircle which is generally observed in P3HT:PCBM OSC and corresponds to the charge transport is absent.,8,9 Therefore, Nyquist plot for PTB7Th:PCBM OSC can be fitted by a simple circuit shown in the Fig. S4 $\uparrow$ which consists of a recombination resistance $\left(R_{\text {rec }}\right)$ and the chemical capacitance $\left(C_{\mu}\right)$ along with the series resistance due to contact and wires $\left(R_{\mathrm{s}}\right)$. The obtained values of resistance and the capacitance after fitting were plotted as a function of $V_{\text {oc }}$ and have been shown in the Fig. 6(a) and (b) respectively. A critical investigation of these curves approves an exponential decrease and increase of resistance and capacitance respectively with the increase in $V_{\text {oc }}$. Thus, it can be concluded that they represents a bulk and interfacial recombination resistance and chemical capacitance. ${ }^{40,51}$ A meaningful analysis of charge recombination processes within the device can be obtained by fitting the recombination resistance and chemical capacitance as a function of $V_{\mathrm{oc}}$ using the exponential laws mentioned in the eqn (3) and (4). ${ }^{52}$ The obtained values of $\alpha$ and $\beta$ can be seen the Table S3. $\uparrow$ Further, the response time representative of the recombination processes is calculated from the characteristic frequency $(\omega)$ at the top of the arc, where $2 \pi \omega=1 / \tau .^{53}$ For all the devices with different ETLs, effective recombination times $(\tau)$ range in the order of $10^{-4}$ to $10^{-6} \mathrm{~s}$. Additionally, as discussed in previous studies, it is feasible to estimate the charger carrier density $(n)$ from the chemical capacitance $\left(C_{\mu}\right)$ using eqn (5). ${ }^{52}$

$$
\begin{aligned}
R_{\mathrm{rec}} & \propto \exp \left(-\beta V_{\mathrm{oc}} / \kappa_{\mathrm{B}} T\right) \\
C_{\mu} & \propto \exp \left(\alpha V_{\mathrm{oc}} / \kappa_{\mathrm{B}} T\right) \\
n & =\frac{1}{e} \int_{0}^{V_{\mathrm{oc}}} C_{\mu}(V) \mathrm{d} V
\end{aligned}
$$

Fig. 6(c) illustrates the carrier lifetime as a function of the photo-generated carrier density. All the curves show decay dynamics that follow a power law trend mentioned in the eqn (6). ${ }^{51}$ The obtained value of $\lambda$ for PTB7-Th:PCBM OSCs with ZnO, $\mathrm{ZnO} / \mathrm{Ba}(\mathrm{OH})_{2}$ and $\mathrm{ZnO}: \mathrm{Ba}(\mathrm{OH})_{2}$ nanocomposite as ETLs are shown in the Table S3. $\dagger$ It is necessary to mention here that the impedance measurements allow to establish a direct relation between the exponents of the capacitance and resistance dependences on $V_{\text {oc }}$, and the power-law exponent of $\tau(n)$ function as mentioned in the eqn (7).51,52 The obtained values of $\lambda$ using the eqn (7) for PTB7-Th:PCBM OSCs with $\mathrm{ZnO}, \mathrm{ZnO} /$ $\mathrm{Ba}(\mathrm{OH})_{2}$ and $\mathrm{ZnO}: \mathrm{Ba}(\mathrm{OH})_{2}$ nanocomposite as ETLs are also shown in the Table S3. $\dagger$

$$
\begin{aligned}
& \tau \propto n^{-\lambda} \\
& \lambda=\frac{\beta}{\alpha}-1
\end{aligned}
$$



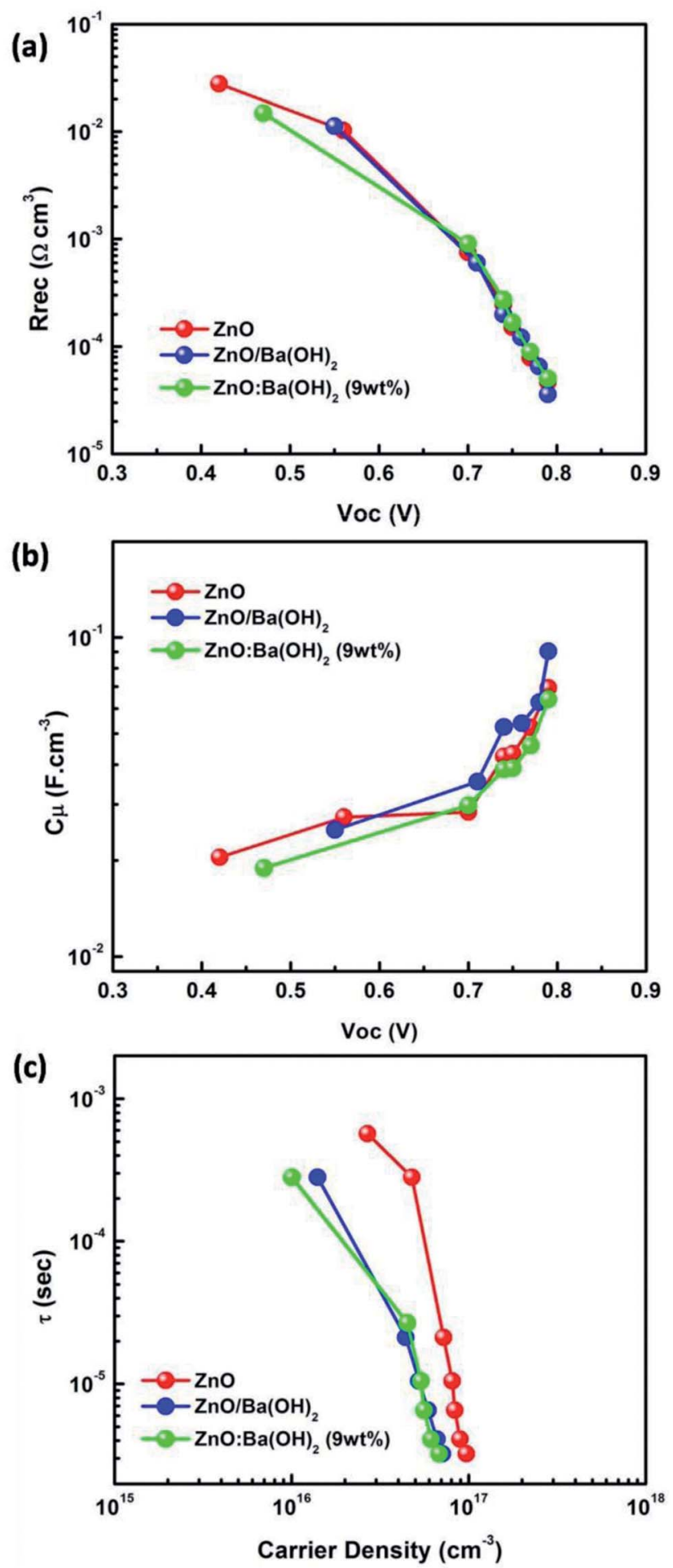

Fig. 6 (a) Recombination resistance $\left(R_{\text {rec }}\right)$ as a function of $V_{\text {oc }}$ (b) chemical capacitance $\left(C_{\mu}\right)$ as a function of $V_{o c}$ (c) carrier lifetime as a function of the photo-generated carrier density for PTB7-Th:PCBM OSCs with ZnO, ZnO/ $\mathrm{Ba}(\mathrm{OH})_{2}$ and $\mathrm{ZnO}: \mathrm{Ba}(\mathrm{OH})_{2}$ nanocomposite as an ETLs.

It can be clearly observed that values of $\lambda$ as obtained from eqn (6) and (7) for the PTB7-Th:PCBM OSCs with $\mathrm{ZnO} / \mathrm{Ba}(\mathrm{OH})_{2}$ and $\mathrm{ZnO}: \mathrm{Ba}(\mathrm{OH})_{2}$ nanocomposite as ETLs are in close agreement suggesting that order of recombination $(1+\lambda)$ depends not only on the features of the density of states but also on the flux of carrier loss through the parameter $\beta$. However, the values of $\lambda$ as obtained from eqn (6) and (7) for the PTB7-Th:PCBM OSCs with ZnO as ETL are different. In this case, the similar value of $\lambda$ (as calculated using eqn (7)) can be obtained by using the relation $\lambda=1 / \alpha$ thereby confirming that order of the recombination exclusively depends on the energy distribution of the trapped states. ${ }^{\mathbf{5 2 , 5 4}}$ This is because the above analyses recognize the recombination as a multiple trapping mechanism in which trapped holes can either recombine with electrons at the acceptor levels or be retrapped at an exponential tail of donor states. ${ }^{52,54}$ Thus, photo-EIS measurements confirms that PTB7-Th:PCBM OSCs with $\mathrm{ZnO} / \mathrm{Ba}(\mathrm{OH})_{2}$ and $\mathrm{ZnO}: \mathrm{Ba}(\mathrm{OH})_{2}$ nanocomposite as ETLs performs better than that of PTB7Th:PCBM OSCs with ZnO as an ETL because the presence of $\mathrm{Ba}(\mathrm{OH})_{2}$ restricts the multiple trapping and minimizes the recombination which was otherwise observed in devices with only $\mathrm{ZnO}$ as an ETL. ${ }^{22}$

\section{Conclusion}

In conclusion, we have compared the device performance of PTB7-Th:PCBM OSCs in an inverted geometry with $\mathrm{ZnO}, \mathrm{ZnO} /$ $\mathrm{Ba}(\mathrm{OH})_{2}$ and $\mathrm{ZnO}: \mathrm{Ba}(\mathrm{OH})_{2}$ nanocomposite as an ETLs. Our study confirms that devices with $\mathrm{ZnO} / \mathrm{Ba}(\mathrm{OH})_{2}$ and $\mathrm{ZnO}: \mathrm{Ba}(\mathrm{OH})_{2}$ nanocomposite as ETL demonstrates improved performance parameters compared to devices with only $\mathrm{ZnO}$ as ETL. It is observed that films of $\mathrm{ZnO} / \mathrm{Ba}(\mathrm{OH})_{2}$ and $\mathrm{ZnO}: \mathrm{Ba}(\mathrm{OH})_{2}$ nanocomposite have low work function and are slightly more smooth and hydrophobic as compared to $\mathrm{ZnO}$ films. This might have suppressed the charge recombination and thereby improved the charge collection as has been confirmed by EIS measurements.

\section{Conflicts of interest}

There are no conflicts to declare.

\section{Acknowledgements}

The authors would like to acknowledge the support of Center of Excellence in Nanoelectronics (CEN), National Center for Photovoltaic Research and Education (NCPRE), Department of Metallurgical Engineering and Materials Science (MEMS) and Sophisticated Analytical Instrument Facility (SAIF) at Indian Institute of Technology Bombay (IIT Bombay) Mumbai for providing various facilities for device fabrication and characterization. A. Y. thanks the DST-INSPIRE fellowship for the financial support. We also thank for partial support under the Solar Energy Research Institute for India and the United States (SERIIUS), funded jointly by the U.S. Department of Energy (Office of Science, Office of Basic Energy Sciences, and Energy Efficiency and Renewable Energy, Solar Energy Technology Program, under Subcontract DE-AC36-08GO28308 to the National Renewable Energy Laboratory, Golden, Colorado) and the Government of India, through the Department of Science 
and Technology under Subcontract IUSSTF/JCERDC-SERIIUS/ 2012 dated 22nd Nov. 2012.

\section{References}

1 G. Yu, J. Gao, J. C. Hummelen, F. Wudl and A. J. Heeger, Science, 1995, 270, 1789-1791.

2 Z. C. He, C. M. Zhong, S. J. Su, M. Xu, H. B. Wu and Y. Cao, Nat. Photonics, 2012, 6, 591-595.

3 W. C. Huang, N. Chandrasekaran, S. K. K. Prasad, E. Gann, L. Thomsen, D. Kabra, J. M. Hodgkiss, Y. B. Cheng and C. R. McNeill, ACS Appl. Mater. Interfaces, 2016, 8, 2960829618.

4 N. Chandrasekaran, E. Gann, N. Jain, A. Kumar, S. Gopinathan, A. Sadhanala, R. H. Friend, A. Kumar, C. R. McNeill and D. Kabra, ACS Appl. Mater. Interfaces, 2016, 8, 20243-20250.

5 N. S. Sariciftci, L. Smilowitz, A. J. Heeger and F. Wudl, Science, 1992, 258, 1474-1476.

6 S. R. Gollu, R. Sharma, G. Srinivas, S. Kundu and D. Gupta, Org. Electron., 2014, 15, 2518-2525.

7 R. Sharma, S. Bhalerao and D. Gupta, Org. Electron., 2016, 33, 274-280.

8 S. R. Gollu, R. Sharma, G. Srinivas, S. Kundu and D. Gupta, Org. Electron., 2015, 24, 43-50.

9 S. R. Gollu, R. Sharma, G. Srinivas, S. Kundu and D. Gupta, Org. Electron., 2016, 29, 79-87.

10 G. Dennler, R. Gaudiana and C. J. Brabec, Abstr. Pap. Am. Chem. Soc., 2009, 238.

11 T. Ameri, P. Khoram, J. Min and C. J. Brabec, Adv. Mater., 2013, 25, 4245-4266.

12 L. Y. Lu, T. Y. Zheng, Q. H. Wu, A. M. Schneider, D. L. Zhao and L. P. Yu, Chem. Rev., 2015, 115, 12666-12731.

13 B. Walker, H. Choi and J. Y. Kim, Curr. Appl. Phys., 2017, 17, 370-391.

14 Z. G. Yin, J. J. Wei and Q. D. Zheng, Adv. Sci., 2016, 3, 1-37. 15 W. C. H. Choy and D. Zhang, Small, 2016, 12, 416-431.

16 H. Zeng, X. C. Zhu, Y. Y. Liang and X. G. Guo, Polymers (Basel), 2015, 7, 333-372.

17 Z. C. Hu, K. Zhang, F. Huang and Y. Cao, Chem. Commun., 2015, 51, 5572-5585.

18 V. Gupta, A. K. K. Kyaw, D. H. Wang, S. Chand, G. C. Bazan and A. J. Heeger, Sci. Rep. UK, 2013, 3, 1-6.

19 S. Woo, W. H. Kim, H. Kim, Y. Yi, H. K. Lyu and Y. Kim, Adv. Energy Mater., 2014, 4, 1-7.

20 A. K. K. Kyaw, D. H. Wang, V. Gupta, J. Zhang, S. Chand, G. C. Bazan and A. J. Heeger, Adv. Mater., 2013, 25, 23972402.

21 Z. A. Tan, S. S. Li, F. Z. Wang, D. P. Qian, J. Lin, J. H. Hou and Y. F. Li, Sci. Rep. UK, 2014, 4, 1-9.

22 S. Kundu, S. R. Gollu, R. Sharma, G. Srinivas, A. Ashok, A. R. Kulkarni and D. Gupta, Org. Electron., 2013, 14, 30833088.

23 R. Sharma, H. Lee, K. Borse, V. Gupta, A. G. Joshi, S. Yoo and D. Gupta, Org. Electron., 2017, 43, 207-213.

24 S. K. Hau, H. L. Yip, N. S. Baek, J. Y. Zou, K. O'Malley and A. K. Y. Jen, Appl. Phys. Lett., 2008, 92, 253301.
25 Z. H. Lin, C. Y. Jiang, C. X. Zhu and J. Zhang, ACS Appl. Mater. Interfaces, 2013, 5, 713-718.

26 H. Zhang, T. Stubhan, N. Li, M. Turbiez, G. J. Matt, T. Ameri and C. J. Brabec, J. Mater. Chem. A, 2014, 2, 18917-18923.

27 S. I. Na, T. S. Kim, S. H. Oh, J. Kim, S. S. Kim and D. Y. Kim, Appl. Phys. Lett., 2010, 97, 253305.

28 H. Choi, J. S. Park, E. Jeong, G. H. Kim, B. R. Lee, S. O. Kim, M. H. Song, H. Y. Woo and J. Y. Kim, Adv. Mater., 2011, 23, 2759-2763.

29 Y. X. Zhu, X. F. Xu, L. J. Zhang, J. W. Chen and Y. Cao, Sol. Energy Mater. Sol. Cells, 2012, 97, 83-88.

30 L. Yan, Y. X. Song, Y. Zhou, B. Song and Y. F. Li, Org. Electron., 2015, 17, 94-101.

31 P. Li, G. Wang, L. Cai, B. F. Ding, D. C. Zhou, Y. Hu, Y. J. Zhang, J. Xiang, K. M. Wan, L. J. Chen, K. Alameh and Q. L. Song, Phys. Chem. Chem. Phys., 2014, 16, 23792-23799.

32 X. Min, F. Y. Jiang, F. Qin, Z. F. Li, J. H. Tong, S. X. Xiong, W. Meng and Y. H. Zhou, ACS Appl. Mater. Interfaces, 2014, 6, 22628-22633.

33 H. C. Chen, S. W. Lin, J. M. Jiang, Y. W. Su and K. H. Wei, ACS Appl. Mater. Interfaces, 2015, 7, 6273-6281.

34 N. Wu, Q. Luo, Z. M. Bao, J. Lin, Y. Q. Li and C. Q. Ma, Sol. Energy Mater. Sol. Cells, 2015, 141, 248-259.

35 X. R. Jia, N. Wu, J. F. Wei, L. P. Zhang, Q. Luo, Z. M. Bao, Y. Q. Li, Y. Z. Yang, X. G. Liu and C. Q. Ma, Org. Electron., 2016, 38, 150-157.

36 L. P. Lu, D. Kabra and R. H. Friend, Adv. Funct. Mater., 2012, 22, 4165-4171.

37 N. K. Kim, D. Khim, Y. Xu, S. H. Lee, M. Kang, J. Kim, A. Facchetti, Y. Y. Noh and D. Y. Kim, ACS Appl. Mater. Interfaces, 2014, 6, 9614-9621.

38 W. C. Zhao, L. Ye, S. Q. Zhang, H. F. Yao, M. L. Sun and J. H. Hou, J. Phys. Chem. C, 2015, 119, 27322-27329.

39 K. Borse, R. Sharma, H. P. Sagar, P. A. Reddy, D. Gupta and A. Yella, Org. Electron., 2017, 41, 280-286.

40 R. Sharma, H. Lee, V. Gupta, H. Kim, M. Kumar, C. Sharma, S. Chand, S. Yoo and D. Gupta, Org. Electron., 2016, 34, 111117.

41 S. H. Liao, H. J. Jhuo, Y. S. Cheng and S. A. Chen, Adv. Mater., 2013, 25, 4766-4771.

42 S. H. Liao, H. J. Jhuo, P. N. Yeh, Y. S. Cheng, Y. L. Li, Y. H. Lee, S. Sharma and S. A. Chen, Sci. Rep., 2014, 4, 1-7.

43 J. B. You, C. C. Chen, L. T. Dou, S. Murase, H. S. Duan, S. A. Hawks, T. Xu, H. J. Son, L. P. Yu, G. Li and Y. Yang, Adv. Mater., 2012, 24, 5267-5272.

44 Q. Q. Sun, F. J. Zhang, J. Wang, Q. S. An, C. Zhao, L. L. Li, F. Teng and B. Hu, J. Mater. Chem. A, 2015, 3, 18432-18441. 45 P. Nachimuthu, Y. J. Kim, S. V. N. T. Kuchibhatla, Z. Q. Yu, W. Jiang, M. H. Engelhard, V. Shutthanandan, J. Szanyi and S. Thevuthasan, J. Phys. Chem. C, 2009, 113, 1432414328.

46 I. Etxebarria, J. Ajuria and R. Pacios, Org. Electron., 2015, 19, 34-60.

47 Y. H. Kim, T. H. Han, H. Cho, S. Y. Min, C. L. Lee and T. W. Lee, Adv. Funct. Mater., 2014, 24, 3808-3814.

48 J. S. Huang, Z. Xu and Y. Yang, Adv. Funct. Mater., 2007, 17, 1966-1973. 
49 Q. Wan, X. Guo, Z. Y. Wang, W. B. Li, B. Guo, W. Ma, M. J. Zhang and Y. F. Li, Adv. Funct. Mater., 2016, 26, 6635-6640.

50 B. B. Sun, D. Y. Zhou, C. Wang, P. Liu, Y. J. Hao, D. W. Han, L. Feng and Y. Zhou, Org. Electron., 2017, 44, 176-182.

51 A. Guerrero, N. F. Montcada, J. Ajuria, I. Etxebarria, R. Pacios, G. Garcia-Belmonte and E. Palomares, J. Mater. Chem. A, 2013, 1, 12345-12354.
52 P. P. Boix, J. Ajuria, R. Pacios and G. Garcia-Belmonte, J. Appl. Phys., 2011, 109, 074514.

53 T. M. Clarke, C. Lungenschmied, J. Peet, N. Drolet and A. J. Mozer, Adv. Energy Mater., 2015, 5, 1-11.

54 M. P. Eng, P. R. F. Barnes and J. R. Durrant, J. Phys. Chem. Lett., 2010, 1, 3096-3100. 